\title{
POLYARTHRITIS IN BEHÇET'S MULTIPLE SYMPTOM COMPLEX
}

\author{
BY \\ R. W. STRACHAN AND F. W. WIGZELL \\ Aberdeen Royal Infirmary
}

\begin{abstract}
Behçet's syndrome (pronunciation Běh-chětt) is usually regarded as a rare condition which lies in the fields of only three specialties-dermatology, ophthalmology, and gynaecology. The convenient label, triple symptom complex, encourages this, the picture entertained being dominated by the three arresting features-recurrent oral and genital ulceration and relapsing iritis. Our debt to this type of concept is recognized, but if this disorder is to be uncovered more frequently, it has outlived its usefulness.
\end{abstract}

Behçet's syndrome is a protean disorder with a wide spectrum of clinical manifestations. Table I (opposite) indicates the specialties involved, reveals the syndrome's considerable capacity for deception, and offers a ready reference for the features to be looked for once the possibility arises. Although eosinophilia and diabetes mellitus have been reported in this syndrome, they have been omitted from the Table because of their infrequency. Marked eosinophilia has been recorded on only two occasions (Silfverskiöld, 1951; Merenlender, Schwartz, and Stafford, 1961). Diabetes mellitus has only once been reported (Fishof, 1960) as developing acutely in this syndrome, and it is tempting to consider it incidental, although this was not the author's view. If the domination of the syndrome by the triad concept is discarded, Table I makes it obvious that the condition frequently enters the diagnostic field and necessitates much careful interrogation and examination.

\section{Arthralgia and Arthritis of Behçet's Syndrome}

The relevant clinical features of 45 subjects described in the literature who showed locomotor symptoms associated with Behçet's syndrome are detailed in Table II (opposite), which shows that arthralgia and arthritis may be present more often than suspected.

The possible association of these features with erythema nodosum further stresses its importance to the rheumatologist. Truelove (1960), in his recent study of the articular manifestations of erythema nodosum, did not mention the syndrome, and other recent dermatological and medical reviews of erythema nodosum make no reference to it (Gordon, 1961; James, 1961), despite their agreement that many cases remain unexplained. It may not be appreciated that this dermatological feature occurs in one-third of cases of this syndrome (France, Buchanan, Wilson, and Sheldon, 1951). These aspects of the syndrome deserve emphasis, as the discipline of rheumatology, being concerned with chronic diseases, is ideally suited to unmasking such a prolonged, deceptive, episodic disorder.

The varying severity of the arthritis and arthralgia is well illustrated in Table II. In some cases the diagnosis of rheumatoid arthritis, Reiter's syndrome, and intermittent hydrarthrosis had been made, but in others, the locomotor symptoms had merely been recorded without comment in the course of detailing full case histories.

Two further cases recorded below illustrate the importance of the syndrome to the rheumatologist and general physician.

Of the total 47 cases listed, 29 were male and 18 female, the mean age at onset being 29.08 years (range 15 to 41 ) and $25 \cdot 22$ years (range 11 to 45 ) respectively. It appears that the arthritis or arthralgia may precede, coincide, or follow, the triad manifestations. In exceptional cases such lengthy periods as 17 or 24 years had separated the development of these features, but the average interval between initial suspicion and adequate confirmation of the diagnosis, whatever the sequence of presentation, was 2 years. 
TABLE I

WIDESPREAD EPISODIC CLINICAL MANIFESTATIONS AND POSSIBLE MODES OF PRESENTATION

\begin{tabular}{|c|c|}
\hline Specialty & Clinical Features \\
\hline Dermatology & $\begin{array}{l}\text { Pyoderma in its various forms-pustules, impetigo, superficial and deep folliculitis, furuncles, cellulitis, simple } \\
\text { ulcerations } \\
\text { Acne-like lesions } \\
\text { Nodose lesions-typical of erythema nodosum, or colourless, unobserved, only slightly tender } \\
\text { "Ulcers"-genital, lips, gums, palate. tongue, mucosa of cheeks or pharynx }\end{array}$ \\
\hline Gynaecology & $\begin{array}{l}\text { Dyspareunia } \\
\text { Vaginal discharge } \\
\text { Ulceration-perineal or vulval (painful or painless), vaginal, cervical }\end{array}$ \\
\hline Ophthalmology & $\begin{array}{l}\text { Episcleritis, conjunctivitis, keratitis } \\
\text { Iritis (often with hypopyon) } \\
\text { Iridocyclitis } \\
\text { "Retinitis"-exudates, haemorrhages, retinal thrombophlebitis } \\
\text { Vitreous haemorrhage } \\
\text { Optic atrophy } \\
\text { Papilloedema }\end{array}$ \\
\hline Surgery & $\begin{array}{l}\text { Inguinal lymphadenopathy or ulceration } \\
\text { Scrotal, perineal, penile ulceration } \\
\text { Epididymitis-sometimes recurrent, not necessarily very painful } \\
\text { Thrombophlebitis } \\
\text { Inferior vena cava thrombosis-in the adolescent and young adult } \\
\text { Thrombosis dorsal vein of penis } \\
\text { Finger-tip gangrene } \\
\text { Cellulitis } \\
\text { Skin ulcers }\end{array}$ \\
\hline E.N.T. Surgery & Pharyngeal or laryngeal lesion superficially suggesting leukoplakia or neoplasia \\
\hline Rheumatology & $\begin{array}{l}\text { "Aches and pains" } \\
\text { Arthralgia } \\
\text { Arthritis } \\
\text { ? Reiter's syndrome }\end{array}$ \\
\hline Venereology & Ulcerative lesions-painless or painful-penile, scrotal, vulval, or perineal \\
\hline Neurology & $\begin{array}{l}\text { Brain-stem Syndrome-as frequently episodic, referred and readily diagnosed as multiple sclerosis-motor } \\
\text { cranial nerve palsies, diplopia, nystagmus, dysarthria, ataxia, limb weakness, pyramidal signs } \\
\text { Meningomyelitic Syndrome-paraplegia, tetraplegia, headache, fever, neck stiffness (C.S.F.-pleocytosis) } \\
\text { Organic Confusional Syndrome-transient or progressing to dementia } \\
\text { Combinations of Above } \\
\text { Other Variants - mixed pyramidal and extra-pyramidal features or picture of benign intracranial hypertension } \\
\quad \text { (intracranial dural sinus thrombophlebitis) }\end{array}$ \\
\hline Gastro-Enterology & $\begin{array}{l}\text { Vague dyspepsia or dysphagia } \\
\text { Aphthous stomatitis }\end{array}$ \\
\hline General Practice & $\begin{array}{l}\text { Any of the above disguises-particularly erythema nodosum, thrombophlebitis migrans, arthritis, "dis- } \\
\text { seminated sclerosis", Reiter's syndrome } \\
\text { Also-malaise, aches and pains, fever, weight loss, sweats, raised E.S.R., albuminuria with "hidden" } \\
\text { aphthous stomatitis or genital ulceration; } \\
\text { false positive skin tests (non-specific skin hypersensitivity); } \\
\text { ? chronic brucellosis }\end{array}$ \\
\hline
\end{tabular}

TABLE II

CLINICAL FEATURES OF 45 SUBJECTS DESCRIBED IN THE LITERATURE, $1932-61$

\begin{tabular}{|c|c|c|c|c|c|c|}
\hline Sex & \begin{tabular}{|c|} 
Age \\
at \\
Onset \\
(yrs)
\end{tabular} & $\begin{array}{l}\text { Features noted before } \\
\text { Joint Involvement }\end{array}$ & Joint Lesions & $\begin{array}{l}\text { Features noted after } \\
\text { Joint Involvement }\end{array}$ & Author & Date \\
\hline Female & 12 & Oro-genital ulcers & $\begin{array}{l}1 \text { to } 2 \text { years from onset, pain and } \\
\text { swelling of knee, ankle, wrist } \\
\text { and finger joints ( } 2 \text { nd and 3rd } \\
\text { metacarpophalangeal) }\end{array}$ & - & Matras & 1932 \\
\hline Female & 16 & Nil & $\begin{array}{l}\text { Arthralgia, particularly in knees, } \\
\text { coincident with vulval ulceration }\end{array}$ & - & \multirow{2}{*}{ Popoff } & \multirow{2}{*}{1938} \\
\hline Female & 31 & Nil & $\begin{array}{l}\text { Arthralgia coincident with buccal } \\
\text { and vulval ulceration }\end{array}$ & - & & \\
\hline
\end{tabular}


TABLE II (continued)

\begin{tabular}{|c|c|c|c|c|c|c|}
\hline Sex & $\begin{array}{c}\text { Age } \\
\text { at } \\
\text { Onset } \\
\text { (yrs) }\end{array}$ & $\begin{array}{c}\text { Features noted before } \\
\text { Joint Involvement }\end{array}$ & Joint Lesions & $\begin{array}{l}\text { Features noted after } \\
\text { Joint Involvement }\end{array}$ & Author & Date \\
\hline Male & 37 & Nil & "Arthritic pains" at onset & $\begin{array}{l}\text { Oral then genital ulcers } \\
\text { "Erythema nodosum-like lesions" } \\
\text { Conjunctival and corneal changes } \\
\text { possibly related to previous } \\
\text { trachoma }\end{array}$ & Ephraim & 1944 \\
\hline Male & 35 & Iritis & $\begin{array}{l}5 \text { years later, pain in joints, oral } \\
\text { and genital ulcers, thrombo- } \\
\text { phlebitis }\end{array}$ & $\begin{array}{l}\text { Iritis, hypopyon, oro-genital ulcer- } \\
\text { ation }\end{array}$ & Adamantiadès & 1946 \\
\hline Male & 19 & $\begin{array}{l}\text { Uveitis } \\
\text { Hypopyon }\end{array}$ & $\begin{array}{l}2 \text { years later, pain in ankles and } \\
\text { shoulders, swelling of right ankle }\end{array}$ & $\begin{array}{l}\text { Scrotal ulceration one year from } \\
\text { onset }\end{array}$ & Curth & 1946 \\
\hline Male & 20 & Nil & $\begin{array}{l}\text { Presented with pain in arms, legs, } \\
\text { forearms, wrists, and right ankle, } \\
\text { coincident with eye and mucosal } \\
\text { lesions } \\
\text { E.S.R. } 12 \mathrm{~mm} . / \mathrm{hr}\end{array}$ & - & $\begin{array}{l}\text { Katzenellen- } \\
\text { bogen }\end{array}$ & 1946 \\
\hline Male & 31 & Oral ulcer 1 year & $\begin{array}{l}\text { Followed by joint pains, partic- } \\
\text { ularly in knee and fingers of } \\
\text { right hand } \\
\text { E.S.R. } 20 \mathrm{~mm} . / \mathrm{hr}\end{array}$ & $\begin{array}{l}\text { Penile and scrotal ulcers } 3 \text { years } \\
\text { from onset }\end{array}$ & & \\
\hline Male & 23 & Erythema nodosum & $\begin{array}{l}\text { Recurrent swelling of interphalan- } \\
\text { geal joints of each thumb }\end{array}$ & $\begin{array}{l}\text { Ulcers in mouth } \\
\text { Bloodshot eye and failing vision } \\
\text { Cranial nerve palsies } \\
\text { Fever } \\
\text { Painless scrotal ulcers } \\
\text { Painful oral ulcers } \\
\text { Iritis } \\
\text { Effusion left knee } \\
\text { Death } 2 \text { years from onset }\end{array}$ & Gray & 1950 \\
\hline Male & 41 & $\begin{array}{l}\text { Ulcer of cheek and } \\
\text { glans penis } \\
\text { Conjunctivitis, uve- } \\
\text { it is, hypopyon, } \\
\text { loss of vision }\end{array}$ & $\begin{array}{l}\text { Arthralgia occurring with these } \\
\text { features, but chronology un- } \\
\text { certain }\end{array}$ & - & Touraine & 1950 \\
\hline Male & 22 & Nil & $\begin{array}{l}\text { Presented with chronic "sprain" of } \\
\text { ankle going on to arthralgia of } \\
\text { knees, shoulders, temporo- } \\
\text { mandibular joint } \\
\text { Painful effusion left knee, knees } \\
\text { and ankles grossly swollen and } \\
\text { tender } \\
\text { E.S.R. } 3 \text { to } 40 \mathrm{~mm} \text {. } / \mathrm{hr} \\
\text { Synovial bionsy-inconclusive } \\
\text { Diagnosis: Reiter's disease, } x \text { ray } \\
\text { negative }\end{array}$ & $\begin{array}{l}\text { Scrotal ulcers } 4 \text { months from onset } \\
\text { Iritis } 8 \text { months from onset }\end{array}$ & $\begin{array}{l}\text { France and } \\
\text { Others }\end{array}$ & 1951 \\
\hline Male & 15 & $\begin{array}{l}\text { Oro-genital ulcers } \\
\quad 1 \text { year }\end{array}$ & $\begin{array}{l}\text { "Migrating polyarthritis" with } \\
\text { fever and weight loss }\end{array}$ & $\begin{array}{l}\text { Choroido-retinitis } \\
\text { Clinical cerebellar and cranial } \\
\text { nerve involvement }\end{array}$ & Curth & 1952 \\
\hline Male & $?$ & Oral ulcers & $\begin{array}{l}9 \text { months later, swollen ankles, } \\
\text { hypopyon, genital ulcers }\end{array}$ & - & Sezer & 1953 \\
\hline Female & 35 & \multirow{6}{*}{$\begin{array}{l}\text { Present, chronology } \\
\text { uncertain }\end{array}$} & \multirow{6}{*}{$\begin{array}{l}\text { Features of joint symptoms: } \\
\text { (1) Predelection for previously } \\
\text { affected joint } \\
\text { (2) Mono-articular } \\
\text { (3) Knees, ankles, wrists com- } \\
\text { monly with limitation and } \\
\text { (4) Effusion with pain of joint function to } \\
\text { (5) Return of armal after attack }\end{array}$} & \multirow{6}{*}{ Present, chronology uncertain } & \multirow{6}{*}{$\begin{array}{l}\text { Phillips and } \\
\text { Scott }\end{array}$} & \multirow{6}{*}{1955} \\
\hline Female & 26 & & & & & \\
\hline Female & 28 & & & & & \\
\hline Female & 24 & & & & & \\
\hline Female & 11 & & & & & \\
\hline Female & 20 & & & & & \\
\hline Male & 35 & $\begin{array}{l}\text { Present chronology } \\
\text { uncertain }\end{array}$ & $\begin{array}{l}\text { Pain in shoulders, elbows, wrists, } \\
\text { back }\end{array}$ & Present, chronology uncertain & Shubert & 1955 \\
\hline Female & 25 & $\begin{array}{l}\text { (?) Pyelitis } \\
\text { After } 3 \text { years mouth } \\
\text { ulcers } \\
2 \text { years later genital } \\
\text { ulcers }\end{array}$ & $\begin{array}{l}5 \text { years from onset (one month } \\
\text { after genital ulceration), acute } \\
\text { generalized arthropathy } \\
\text { Diagnosed and treated as rheuma- } \\
\text { toid arthritis }\end{array}$ & $\begin{array}{l}\text { Blurred vision, iridocyclitis, oral } \\
\text { and vaginal ulcers } 11 \text { years from } \\
\text { onset } \\
\text { E.S.R. } 104 \mathrm{~mm} . / \mathrm{hr} \\
\text { No residual deformity in joints }\end{array}$ & $\begin{array}{l}\text { Linton and } \\
\text { Saint }\end{array}$ & 1956 \\
\hline
\end{tabular}


TABLE II (continued)

\begin{tabular}{|c|c|c|c|c|c|c|}
\hline Sex & $\begin{array}{c}\text { Age } \\
\text { at } \\
\text { Onset } \\
\text { (yrs) }\end{array}$ & $\begin{array}{c}\text { Features noted before } \\
\text { Joint Involvement }\end{array}$ & Joint Lesions & $\begin{array}{l}\text { Features noted after } \\
\text { Joint Involvement }\end{array}$ & Author & Date \\
\hline Male & 30 & Nil & "Acute polyarticular rheumatism" & $\begin{array}{l}\text { Pain in eye and oro-genital ulcera- } \\
\text { tion } 1 \text { year later } \\
\text { Later hypopyon and blindness }\end{array}$ & \multirow{14}{*}{ Sezer } & \multirow{14}{*}{1956} \\
\hline Male & 24 & Nil & "Rheumatism" & $\begin{array}{l}\text { Oro-genital ulcers, hypopyon, } \\
\text { blindness, iritis } 2 \text { years later }\end{array}$ & & \\
\hline Male & 25 & $\begin{array}{l}\text { Oro-genital ulcers } \\
\text { Cloudy vision }\end{array}$ & 2 years later "swollen joints" & Deteriorating visual acuity & & \\
\hline Male & 22 & Nil & $\begin{array}{l}\text { "Knees swollen and reddish" } \\
\text { Coincident oral and tonsillar } \\
\text { ulcers }\end{array}$ & - & & \\
\hline Male & 38 & Nil & "Swollen joints and severe pains" & $\begin{array}{l}\text { Hazy vision with pain in eyes, } \\
\text { hypopyon, oro-genital ulcers } \\
\text { about a year later }\end{array}$ & & \\
\hline Male & 17 & Scrotal ulcers & At 23 years of age, “joint swelling”" & $\begin{array}{l}\text { At } 30 \text { years of age, congestion of } \\
\text { eye, hypopyon, blindness }\end{array}$ & & \\
\hline Male & $?$ & Nil & $\begin{array}{l}\text { Started with "rheumatic pains and } \\
\text { joint swelling" }\end{array}$ & Oro-genital ulcers & & \\
\hline Male & $?$ & Nil & Ditto & Ditto & & \\
\hline Male & 26 & Nil & $\begin{array}{l}\text { Ankle swelling } \\
\text { Coincident oro-genital ulcers }\end{array}$ & - & & \\
\hline Female & 28 & Nil & $\begin{array}{l}\text { Coincident "rheumatism" and oro- } \\
\text { genital ulcers }\end{array}$ & $\begin{array}{l}\text { Ciliary congestion } \\
\text { Hypopyon }\end{array}$ & & \\
\hline Male & $?$ & Nil & "Polyarticular rheumatism" & $\begin{array}{l}\text { Uveitis, oro-genital ulcers, hypo- } \\
\text { pyon } 10 \text { years later }\end{array}$ & & \\
\hline Male & 30 & Nil & $\begin{array}{l}\text { Coincident "rheumatism" and oro- } \\
\text { genital ulcers }\end{array}$ & $\begin{array}{l}\text { Oro-genital ulcers, iridocyclitis } \\
\text { with hypopyon } 14 \text { years later }\end{array}$ & & \\
\hline Male & 21 & Nil & $\begin{array}{l}\text { Coincident "joint swelling" and } \\
\text { oro-genital ulcers }\end{array}$ & - & & \\
\hline Male & 23 & Oro-genital ulcers & $\begin{array}{l}3 \text { years later, joint swelling and eye } \\
\text { pain }\end{array}$ & Iridocyclitis & & \\
\hline Female & 36 & Retinitis for 5 years & $\begin{array}{l}\text { Painful swelling of both knees } \\
\text { followed in a month by swelling } \\
\text { of index and middle fingers } \\
\text { Continued swelling of right knee } \\
\text { alone } \\
\text { Diagnosis-rheumatoid arthritis }\end{array}$ & Vulval ulcers & $\begin{array}{l}\text { Wadia and } \\
\text { Williams }\end{array}$ & 1957 \\
\hline Female & 25 & Nil & $\begin{array}{l}\text { Presented after } 5 \text { years of recurrent } \\
\text { hydrarthrosis of one or both } \\
\text { knees and ankles }\end{array}$ & $\begin{array}{l}\text { Vulval and oral ulcers } 3 \text { to } 4 \text { years } \\
\text { after onset } \\
\text { Progress to right hemiblegia and } \\
\text { mental and retinal changes }\end{array}$ & Whitty & 1958 \\
\hline Male & 29 & Nil & $\begin{array}{l}\text { Presented with pain and stiffness in } \\
\text { right elbow unaffected by aspira- } \\
\text { tion and intra-articular steroid } \\
4 \text { months from onset effusion in } \\
\text { knee-diagnosed "? rheuma- } \\
\text { toid arthritis", but negative } \\
\text { Waaler-Rose test and psoriatic } \\
\text { lesions present }\end{array}$ & $\begin{array}{l}\text { Scrotal and oral ulcers } 6 \text { and } 7 \\
\text { months from onset } \\
\text { Progress to thrombophlebitis of a } \\
\text { dural sinus and papilloedema } \\
\text { E.S.R. } 91 \mathrm{~mm} . / \mathrm{hr}\end{array}$ & Masheter & 1959 \\
\hline Female & 36 & \multirow[t]{3}{*}{$\begin{array}{l}\text { Present, chronology } \\
\text { uncertain }\end{array}$} & $\begin{array}{l}\text { "Migrating polyarthritis most pro- } \\
\text { minent symptom" }\end{array}$ & Present, chronology uncertain & \multirow{4}{*}{ Berlin } & \multirow{4}{*}{1960} \\
\hline Male & 29 & & "Arthropathy" & & & \\
\hline Female & 18 & & "Arthropathy" & & & \\
\hline Male & 17 & “Urethritis”' & $\begin{array}{l}\text { Presented with pain and swelling } \\
\text { in right thigh and knee with } \\
\text { "arthrobathy" in } 9 \text { months } \\
X \text { ray negative }\end{array}$ & $\begin{array}{l}\text { Uveitis, stomatitis, indigestion, } \\
\text { rash, subcutaneous nodules in } \\
\text { one month }\end{array}$ & & \\
\hline
\end{tabular}


TABLE II (continued)

\begin{tabular}{|c|c|c|c|c|c|c|}
\hline Sex & $\begin{array}{c}\text { Age } \\
\text { at } \\
\text { Onset } \\
\text { (yrs) }\end{array}$ & $\begin{array}{l}\text { Features noted before } \\
\text { Joint Invo!vement }\end{array}$ & Joint Lesions & $\begin{array}{l}\text { Features noted after } \\
\text { Joint Involvement }\end{array}$ & Author & Date \\
\hline Male & $?$ & $\begin{array}{l}\text { Recurrent small nod- } \\
\text { ules on arms and } \\
\text { legs going on to } \\
\text { pustules }\end{array}$ & $\begin{array}{l}\text { Painful, swollen right ankle } \\
\text { Tender extensor muscles of arms } \\
\text { and legs } \\
\text { Tender subcutaneous nodule on } \\
\text { ankle }\end{array}$ & Blindness & Fishof & 1960 \\
\hline Female & 12 & $\begin{array}{l}\text { Oral ulcers, iritis, } \\
\text { hypopyon } \\
\text { Vaginal ulcers }\end{array}$ & $\begin{array}{l}\text { At } 36 \text { years of age, presented with } \\
\text { recurrent attacks of pain and } \\
\text { swelling in both ankles and } \\
\text { "knuckles" }\end{array}$ & $\begin{array}{l}\text { Blindness } \\
\text { Reactive depression } \\
\text { Continuing oral ulcers and scarring }\end{array}$ & Semmence & 1960 \\
\hline Male & $\begin{array}{l}\text { App- } \\
\text { rox. } \\
17\end{array}$ & Conjunctivitis & 2 years later, pain in ankle joint & $\begin{array}{l}\text { Ankle pain and swelling } 15 \text { years } \\
\text { from onset } \\
\text { Conjunctivitis, erythema nodosum, } \\
\text { avhthous stomatitis, retinitis, } \\
\text { scrotal and penile ulcers, balan- } \\
\text { itis } \\
\text { E.S.R. } 33 \mathrm{~mm} / \mathrm{hr} \\
2 \text { years later polyarthritis and } \\
\text { retinal vein thrombosis }\end{array}$ & $\begin{array}{l}\text { Falck and } \\
\text { Schmidt }\end{array}$ & 1961 \\
\hline
\end{tabular}

\section{Case Reports}

Case 1, a woman now aged 53, first complained of painful swollen fingers at the age of 26 years. She had been investigated at that time in the Medical OutPatient Department, diagnosed as having rheumatoid arthritis, and given gold by intramuscular injection, with heat and exercises. This was followed by a period of relief, but, over the following years she had six similar attacks.

The last of these, being particularly severe, had brought her to the Out-Patient Department again in 1956 at the age of 47 years. Examination showed spindling of the fingers (Fig. 1) and pain and swelling in the left ankle. Although the fist formed well, her grip was poor (Fig. 2, opposite). $X$ rays of the hands showed no abnormality. Another period of improvement followed.
In 1957 she complained of lassitude and of pain in the knees. The erythrocyte sedimentation rate (Westergren) was $8 \mathrm{~mm}$. in the first hour. Later that year there was further swelling and pain in the fingers, and pain in the right shoulder and wrist. At this stage the erythrocyte sedimentation rate had risen to $18 \mathrm{~mm}$./ $/ \mathrm{hr}$. For the first time she complained of post-prandial heartburn unrelated to posture.

During 1958 swelling of the left knee and marked stiffness of the shoulders became troublesome, and there was morning stiffness of the hands. Injections of hydro cortisone acetate suspension into the proximal interphalangeal joints of the fingers brought no improvement.

Examination at this time showed active arthritis in the left tarsus, ankle, and knee. There was limitation of movement of the shoulders. The wrists were swollen

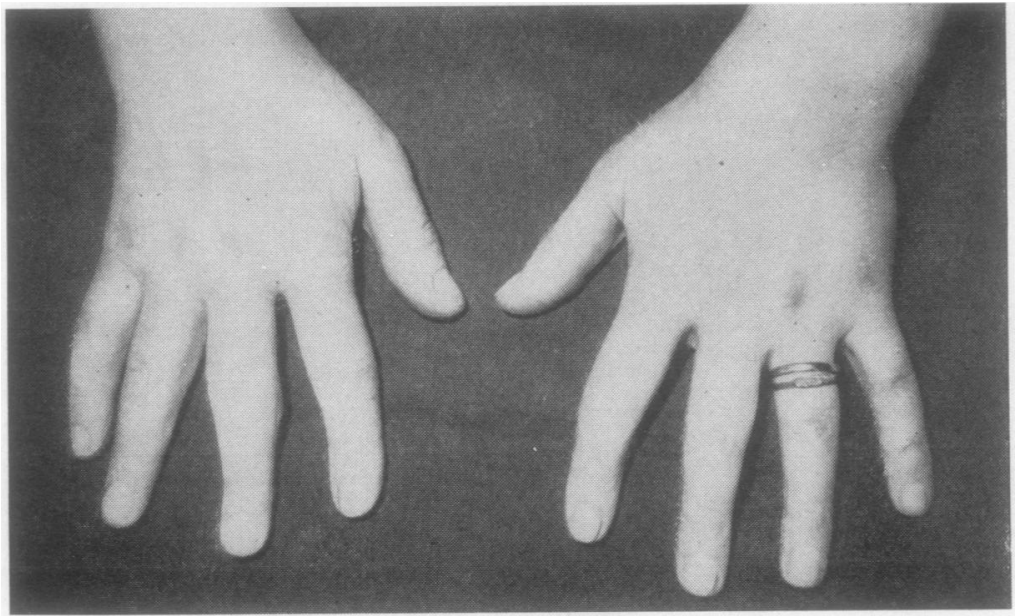

Fig. 1. Case 1, showing appearance of hands. 


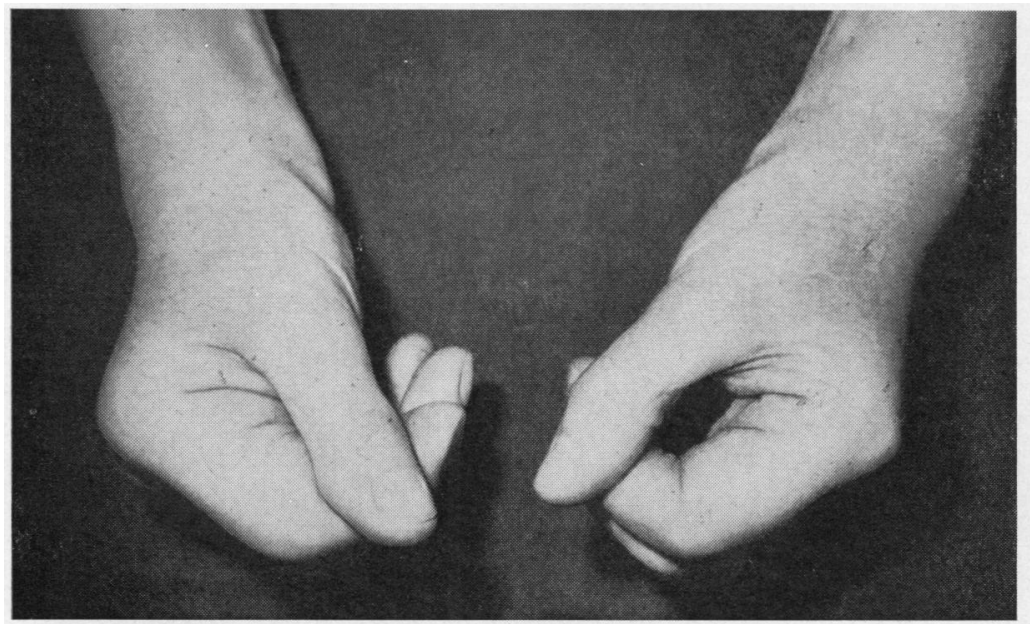

Fig. 2. Case 1, showing appearance of fists.

and tender. Tenderness of the metacarpophalangeal joints and of the proximal interphalangeal joints was noted, together with spindling of the latter.

Laboratory Investigations.-Hb 76 per cent. (11.2 g. per cent.); white blood count 2,000 per c.mm.; polymorphs 60 per cent.; eosinophils 8 per cent.; plasma proteins $5 \cdot 2$ g. per cent. with a normal ratio; gonococcal complement-fixation test, Wassermann reaction, and Kahn test all negative. Waaler-Rose test negative. L.E.-cell test repeatedly negative. Brucella agglutination test negative. Erythrocyte sedimentation rate 10 and $14 \mathrm{~mm}$./hour.

$X$ rays showed no abnormality in the chest, knees, shoulders, and sacro-iliac joints, and only slight periarticular osteoporosis in the feet. No bony changes were seen in the hands.

Barium meal examination revealed a small hiatus hernia.

The presumptive diagnosis was that of rheumatoid arthritis (sero-negative). Treatment with physiotherapeutic measures, splints, and analgesics, led to some improvement, but 5 months later the arthritis in the fingers was still active. The haemoglobin remained at 79 per cent. (11.5 g. per cent.), the white blood count was 5,400 per c.mm., and the erythrocyte sedimentation rate had risen to $22 \mathrm{~mm}$./hr. In view of the persistent symptoms in the wrists and finger joints, the increasing erythrocyte sedimentation rate, and anaemia, a course of sodium aurothiomalate was given by intra-muscular injection. Careful direct questioning during this treatment not only uncovered the presence of painful aphthous mouth ulceration, but also a history of its episodic occurrence for more than 10 years. This exonerated the gold therapy and, as her joint condition showed marked improvement, the course was completed to a total dose of $1 \mathrm{~g}$. in 10 months. The haemoglobin remained between 70 and 80 per cent. during this period, and the white blood count within normal limits.
In 1959 , shortly after cessation of the gold therapy, there was a recrudescence of active arthritis in the fingers, and at the end of that year her feet and hands were again very painful, and there was marked inability to flex the fingers. There was pain in the right shoulder with limitation of movement. Because of this relapse she was given oral methylprednisolone (2-4 mg. daily for 19 weeks), and later hydroxyphenylbutazone was tried without benefit. During this time erythrocyte sedimentation rate readings of between 34 and $55 \mathrm{~mm}$./hr were recorded. Neither the Waaler-Rose test nor the R.A. latex test gave a positive result. The fluorescent antibody test failed to show antinuclear activity in the serum. The white blood count was at the lower limit of normal, but the haemoglobin had risen to 90 per cent.

Later in 1960 a further course of methylprednisolone (4 mg. daily for 14 weeks) appeared to improve the joint state, particularly in the ease with which she could use her hands.

In 1961 methylprednisolone was given once more, but in higher dosage $(8 \mathrm{mg}$. daily for 16 weeks). On this occasion there was little change in the joint condition or relief from the regular appearance every few weeks of painful mouth ulcers involving the tongue, buccal mucosa, and gums. Dental examination showed no oral cause for these. Neither the application of gentian violet nor hydrocortisone pellets (Corlan) helped.

The continuing polyarthritis, unaffected by treatment, and the episodic aphthous mouth ulceration, were now joined by a severe unilateral conjunctivitis and several extremely painful ulcers of the labia. The conjunctivitis persisted for 3 weeks. These new features were elicited only by direct questioning, and the painful vulval ulcers had in fact been present for some months without spontaneous complaint.

Therefore, with an ill-defined polyarthritis extending over many years, there had now appeared sufficient features to support the diagnosis of Behçet's syndrome. 
Case 2, a farmer's wife aged 45, was admitted to hospital in December, 1961, with a 7 weeks' history of aphthous ulceration of the gums and buccal mucosa, and severe vulval pain due to several small excavated ulcers of the labia minora which had been present for 6 weeks. Neither feature had occurred previously. There was no history of eye trouble, although she had been practically blind in the right eye all her life. No lesion was detected and the blindness was considered to be due to amblyopia ex anopsia.

Her earlier health had been good, showing none of the features in Table I, apart from a complaint of "joint pains". For 15 months, however, recurrent episodes of aching pain in the knees, shoulders, ankles, several proximal interphalangeal finger joints, and the metatarsophalangeal joints had been troublesome, and an outpatient assessment 9 months earlier recorded no abnormality on examination or $x$ ray of the hands. The erythrocyte sedimentation rate was normal. The response to Solprin, paracetamol, Bufferin, methylprednisolone (Medrone), phenylbutazone, and chloroquine prescribed by her general practitioner had not been impressive. (The investigations subsequently excluded any possible relation between the ulcerative lesions and the phenylbutazone.) The steroid therapy was given for only 6 weeks, the maximum dosage being $12 \mathrm{mg}$. methylprednisolone daily; it had been gradually withdrawn because of the lack of response and had been discontinued altogether a few days before the aphthous stomatitis appeared.

During her first admission, fever of 99 to $100^{\circ} \mathrm{F}$. was recorded on several occasions, and the E.S.R. (Westergren) repeatedly stood at $60 \mathrm{~mm}$. in the first hour. The mouth ulcers resolved in a few days, apparently because of the administration of hydrocortisone pellets (Corlan), and rapid relief from pain with healing of the vulval ulcers in a week occurred after topical application of Tri-Adcortyl ointment (Squibb).
During the next 4 months, three out-patient reviews showed that the E.S.R. remained markedly raised $(54,41,38 \mathrm{~mm}$.). Vulval pain but not actual ulceration occurred on one further occasion. The major disability was due to the persistence of the arthralgia, the right wrist and ankle and the proximal interphalangeal hand joints being particularly troublesome. Obvious spindling of two fingers appeared (Fig. 3) and pain and stiffness of the right hip joint became troublesome. She appeared pale, ill, tired, and crippling in the out-patient department in March, 1962, and a further hospital admission of 17 days was necessary. Drug therapy for the joint symptoms since her first admission had consisted of Solprin, and chloroquine was added during this second admission. The response was only moderate.

Laboratory Investigations.-During these 5 months of observation the following investigations had been carried out: $X$ ray of chest, hands, feet, sacro-iliac joints, knees. ankles-normal; blood count-Hb (i) 74 per cent, (10.8 g. per cent.), (ii) 82 per cent. (12.0 g. per cent.), white blood count (i) 8,250, (ii) 7,450 per c.mm.; normal differential counts-only 1 per cent. eosinophils. Ulcer swabs, mouth and vulva, no significant growth; no virus isolated. Blood Wassermann reaction, Meinicke test, Price's precipitation reaction, and gonococcal complement-fixation test-all negative. Brucella agglutination test-negative; brucellin skin test-negative. R.A. latex and Waaler-Rose tests negative on three occasions. L.E.-cell test repeatedly negative; antistreptolysin titre80 units $/ \mathrm{ml}$.; serum electrophoresis-slightly increased gamma and alpha-2 globulins; fibrinogen-less than 0.1 g. per cent.; fluorescent antibody test-serum showedko no antinuclear activity. Serum glutamic-oxalacetic: transaminase 18 units; serum glutamic-pyruvate transaminase 16 units; serum alkaline phosphatase-9.3 KingArmstrong units $/ 100 \mathrm{ml}$. serum; bromsulphthalein testno dye present in $45-\mathrm{min}$. serum sample; thymol turbidity -2 units; serum bilirubin- $0.2 \mathrm{mg}$. per cent.

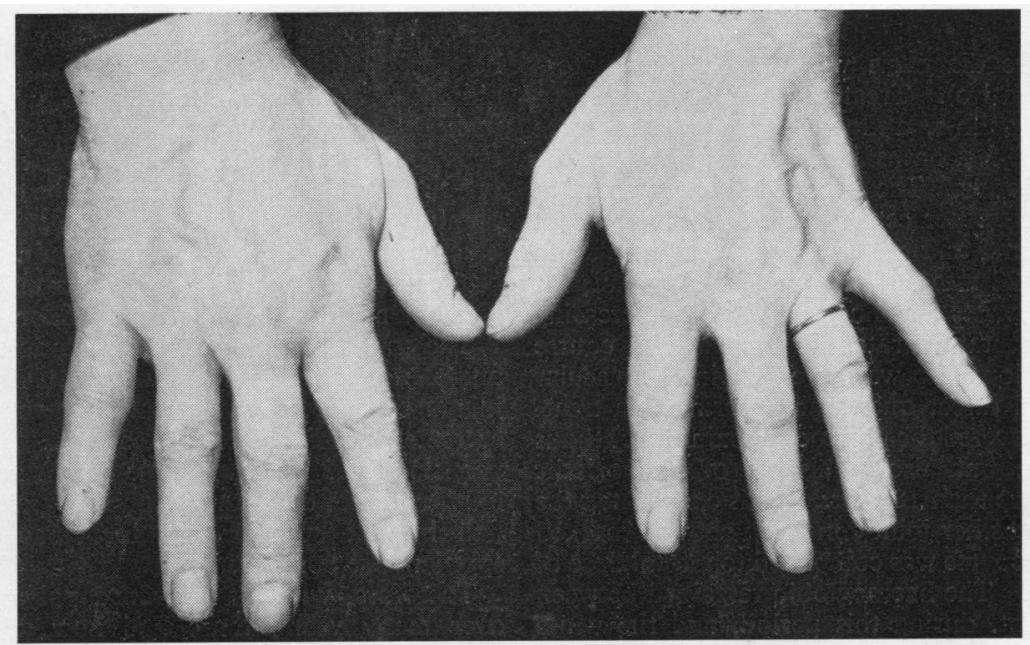

Fig. 3. Case 2, showing appearance of hands. 
Differential Diagnosis

A number of conditions with articular manifestations need consideration in the differential diagnosis of Behçet's multiple symptom complex, especially in young patients.

Rheumatoid Disease.-Points of similarity include a prolonged relapsing course, anaemia, raised erythrocyte sedimentation rate, mono-arthritis or polyarthritis, spindling of the fingers, purulent sterile joint effusions, subcutaneous nodules, fever, and loss of weight. Although at times involving the small joints of the hands, Behçet's syndrome for the most part affects the large joints.

A positive Waaler-Rose test, marginal joint erosions, erythematous palms, and ulnar deviation are seen only in rheumatoid arthritis, which is more commonly found in middle-aged females, whereas Behçet's syndrome occurs predominantly in young males.

Leg ulceration is found in both (Allison and Bettley, 1957; Pallis and Fudge, 1956). Familial occurrence of Behçet's syndrome (Berlin, 1960; Forbes and Robson, 1960; Sezer, 1956) has been recorded, but infrequently, and in this way it resembles rheumatoid arthritis. The greatest difficulty will be experienced in differentiating seronegative rheumatoid arthritis of atypical (or asymmetrical) onset. Intermittent hydrarthrosis, thought by some to be a variant of rheumatoid arthritis, can also be closely imitated by Behçet's syndrome.

Reiter's Syndrome (polyarthritis, conjunctivitis (sometimes iritis or uveitis) and urethritis).-This requires careful separation from Behçet's syndrome. Similarities other than the age and sex distribution, are the oro-genital ulceration and the generally favourable prognosis of the joint involvement. Failure to elicit or to recognize the significance of oro-genital symptomatology and the similar episodic pattern, often with incomplete clinical expression of the major features at any one time, adds to the difficulties. Painful aphthous mouth ulceration constant in Behçet's syndrome, has been recorded in Reiter's syndrome (Baron, 1960). Sterile urethritis with blood and pus in the urine, and painless maculopapular rash or ulcerative lesions of the glans penis and prepuce, are characteristic of Reiter's syndrome. However, the latter (and rheumatoid arthritis) may be precipitated by gonococcal urethritis. The ulcerative genital lesions of Behçet's syndrome are usually considered to be exceedingly painful, but this is not entirely true. Relapse following coitus or dysentery appears characteristic of Reiter's syndrome, although post-coital exacerbation occurred in one subject recorded by Fishof (1960). The arthritis may be migratory in either condition, but only in Reiter's syndrome do we find symmetry of joint involvement, sacro-iliac joint changes, radiological evidence of bone destruction, and calcaneal spurs. The hyperkeratotic skin lesions and keratodermia blennorrhagica of Reiter's syndrome could be confused with the pyoderma of Behçet's syndrome. Reiter's syndrome seldom begins with uveitis or progresses to blindness, but in Behçet's syndrome the eye lesions may be extremely serious.

Rheumatic Fever.-The onset may simulate Behçet's syndrome, with malaise, fever, weight loss, and a migratory polyarthritis involving the large joints. Anaemia, raised erythrocyte sedimentation rate, nodose lesions, and occasionally sore throat are features common to both. Differences are found in the antistreptolysin titre, salicylate response, and presence of erythema marginatum.

Still's Disease and Ankylosing Spondylitis.-The rare spinal involvement in the former and the almost invariable backache of the latter are simulated in some cases of Behçet's syndrome by back pain.

These last three conditions and rheumatic fever, all occurring in young people, commonly give a negative Waaler-Rose test.

Erythema Multiforme Exudativum (Stevens-Johnson Syndrome). - The ulcerative lesions in the mouth, perineum, genito-urinary tract, and eyes, and occasional joint effusion, deserve mention in the differential diagnosis. However, superficial sloughing and ulceration of the whole of the oral mucosa is said to differentiate this condition from Behçet's triad (Church and Sneddon, 1955).

Systemic Lupus Erythematosus.-Arthralgia, arthritis, fever, neutropenia (which occurs in some subjects with Behçet's syndrome: Pappworth, 1941), papular skin lesions (Gold, 1954), and occasional oral ulcers (Harvey, Shulman, Tumulty, Conley, and Schoenrich, 1954), must be considered in the differential diagnosis. Mouth ulceration, arthralgia, and eosinophilia occur in polyarteritis nodosa. As indicated, eosinophilia has been recorded in two cases of Behçet's syndrome.

Lymphogranuloma Venereum.-Asymptomatic genital sores and either acute or chronic arthritis, often polyarticular, may be classified by serological and skin tests. 
Pyogenic and Tuberculous Arthritis.-If only one joint is affected, Behçet's syndrome should be considered.

\section{Discussion}

The suggestion of Berlin (1960) that this condition should be remembered not as a triple symptom complex, but as Behçet's multiple symptom complex is fully justified. Reviews which have drawn attention to some of the many non-triad features leave the impression that these are largely incidental (Berlin, 1944; Curth, 1946; France and others, 1951; Phillips and Scott, 1955; Pallis and Fudge, 1956; Berlin, 1960), do not encourage the attitude that the features listed in Table I provide a useful starting point for the recognition of this curious disorder, and do not clearly indicate the difficulty of uncovering even the three most usual symptoms.

The manifestations are episodic, the history often extending over many years, and during any one phase of activity only one of the triad may be present; 10 years or more may separate the appearance of oro-genital ulcers and ocular lesions (Phillips and Scott, 1955; Semmence, 1960), or even the genital and oral lesions. The scarcity of reports in British and American literature suggest that the diagnosis is sometimes missed, although Phillips and Scott (1955) recognized ten cases within $3 \frac{1}{2}$ years at the gynaecological clinics of the United Birmingham Hospitals. Pappworth (1955) refers to over a hundred cases of associated recurrent vaginal and oral ulceration. This series included eight young women doctors, all of whom informed him that they knew many people similarly affected. These reports suggest a higher incidence than is generally thought to exist, and it appears likely that the diagnosis is being overlooked even in the three specialties overtly involved, and that it is being insufficiently considered in other specialties.

There are many reasons why cases go undiagnosed even when the full triad is present. The fear and stigma of venereal disease undoubtedly prevent patients with genital ulcers from seeking help until they become unbearably painful. This was the mode of presentation in Case 2, but in spite of similar pain this vital feature was only uncovered in Case 1 by direct questioning. However, marked pain is not a constant feature (Morrison, 1959; Wadia and Williams, 1957; Gray, 1950), and in such cases spontaneous complaint is most unlikely. The gynaecologist might therefore profitably routinely enquire about such ulceration. In this specialty direct questioning is likely to produce a truthful answer; but in other fields, particularly if the ulcers have healed, their occurrence may be denied because of the possibility of unexpected gynaecological examination, and direct questioning should be couched in reassuring terms indicating that examination is not essential. Modesty in interrogation and examination assisted syphilis in acquiring its reputation as a great imitator, and no doubt plays a part in our failure to recognize Behçet's syndrome more frequently. The ulceration may be hidden to both patient and doctor on the vaginal wall, the only complaint being that of vaginal discharge (Phillips and Scott, 1955). Katzenellenbogen (1946) described a case in which superficial ulceration was seen during urethroscopic examination.

The value of the triad concept is further undermined by somewhat similar difficulties in relation to the aphthous mouth ulceration, which are increased by the surfeit of confusing terminology (Pappworth, 1941; Ship, Merritt, and Stanley, 1962; Sircus, Church, and Kelleher, 1957; Forbes and Robson, 1960). There is probably no case on record in which mouth ulceration has not been present, but this again must be sought with care. After the initial trouble, perhaps 15 or 20 years earlier the patient may well make no further spontaneous complaint, despite episodic recurrences of the ulcers. Therefore direct questioning is again necessary. As with the genital lesions, the neurologist confronted with a difficult diagnostic problem or a picture suggestive of disseminated sclerosis (Pallis and Fudge, 1956; Phillips and Scott, 1955; Masheter, 1959; Curth, 1952; Whitty, 1958; Evans, Pallis, and Spillane, 1957; Lancet, 1958) is unlikely to look for these mouth ulcers or their scars or to try to elicit the history of their episodic occurrence. The ophthalmologist and rheumatologist are equally likely to overlook these features, for in the recognized major textbooks of these three specialties accounts of Behçet's syndrome are inadequate or non-existent.

\section{Conclusions}

The field of rheumatology is particularly well suited for a search for cases of Behçet's multiple symptom complex, since arthritis and arthralgia, with or without erythema nodosum, may be the presenting or dominant feature. The acceptance of the protean nature of the clinical manifestations of sarcoidosis did much to further our knowledge of this disorder and it appears that a similar approach to Behçet's syndrome is justified. The neurologist should consider this syndrome whenever the possibility of multiple sclerosis arises, or when he is faced with a diagnostic problem. The surgeon and general physician should add it to the differential diagnosis of a variety of complaints. The gynaecologist should enquire routinely about painful 
or painless genital ulceration and aphthous stomatitis. In the presence of either, the manifestations listed in Table I should be sought and long-term observation undertaken. The burden of the dermatologists and general practitioners is obvious. Their attention may most profitably be directed towards a search for the many non-triad features in cases presenting with erythema nodosum, aphthous stomatitis, or any of the pyodermas. In many cases only suspicion sustained over the years will confirm the diagnosis.

\section{Summary}

Two cases of Behçet's multiple symptom complex are recorded, in which a persistent rheumatoid type of arthritis was the presenting and dominant feature. The relevant literature of the arthritic and arthralgic aspects is reviewed and the differential diagnosis is discussed. The limitations of the triad concept are indicated. It is suggested that the presence of the non-triad features should initiate consideration of the syndrome in nearly all cases of vaguely-defined symptomatology.

We wish to thank Dr. Ian Gordon and Dr. L. S. Bain for the opportunity of studying these cases which were seen both in Aberdeen Royal Infirmary and in the Department of Physical Medicine and Rheumatology, City Hospital. We have pleasure in acknowledging their encouragement and advice in the preparation of this paper.

\section{REFERENCES}

Adamantiadès, B. (1946). Ann. Oculist. (Paris), 179, 143. Allison, J. H., and Bettley, F. R. (1957). Lancet, 1, 288. Baron, J. H. (1960). Brit. J. clin. Pract., 14, 679.

Berlin, C. (1944). Arch. Derm. Syph. (Chicago), 49, 227. (1960). Ibid., 82, 73.

Church, R. E., and Sneddon, I. B. (1955). Lancet, 1, 511.

Curth, H. O. (1946). Arch. Derm. Syph. (Chicago), $54,179$.

- (1952). Ibid., 66, 761.

Ephraim, H. (1944). Ibid., 50, 37.

Evans, A. D., Pallis, C. A., and Spillane, J. D. (1957). Lancet, 2, 349.

Falck, I., and Schmidt, G. (1961). Med. Klin., 56, 1744.

Fishof, F. E. (1960). J. int. Coll. Surg., 34, 213.

Forbes, I. J., and Robson, H. N. (1960). Brit. med. J., 1, 599.

France, R., Buchanan, R. N., Wilson, M. W., and Sheldon, M. B., Jr. (1951). Medicine (Baltimore), 30, 335.

Gold, S. C. (1954). Brit. J. Derm., 66, 429.

Gordon, H. (1961). Ibid., 73, 393.

Gray, G. S. (1950). Canad. med. Ass. J., 62, 597.

Harvey, A. M., Shulman, L. E., Tumulty, P. A., Conley, C. I., and Schoenrich, E. H. (1954). Medicine (Baltimore), 33, 291.
James, D. G. (1961). Brit. med. J., 1, 853.

Katzenellenbogen, I. (1946). Brit. J. Derm., 58, 161.

Lancet Annotation (1958). 1, 421.

Linton, R. G., and Saint, E. G. (1956). Med. J. Aust., $1,502$.

Masheter, H. C. (for Parkinson, T.) (1959). Proc. roy. Soc. Med., 52, 1039.

Matras, A. (1932). Arch. Derm. Syph. (Berlin), 166. 491.

Merenlender, I. J., Schwartz, B., and Stafford, J. L. (1961). Brit. J. Derm., 73, 273.

Morrison, A. W. (1959). J. Laryng., 73, 833.

Pallis, C. A., and Fudge, B. J. (1956). A.M.A. Arch. Neurol. Psychiat., 75, 1.

Pappworth, M. H. (1941). Brit. med. J., 1, 271. (1955). Lancet, 1, 820.

Phillips, D. L., and Scott, J. S. (1955). Lancet, 1, 366

Popoff, L. (1938). Bull. Soc. franc. Derm. Syph., 45, 1254.

Semmence, A. (1960). Scot. med. J., 5, 267.

Sezer, F. N. (1953). Amer. J. Ophthal., 36, 301. (1956). Ibid., 41, 41.

Ship, I. I., Merritt, A. D., and Stanley, H. R. (1962). Amer. J. Med., 32, 32.

Sircus, W., Church, R., and Kelleher, J. (1957). Quart. J. Med., 26, 235.

Silfverskiöld, B. P. (1951). Acta psychiat. neurol. scand., 26, 443.

Shubert, S. (1955). Lancet, 1, 511.

Touraine, A. (1950). Bull. Soc. franç. Derm. Syph., $57,303$.

Truelove, L. H. (1960). Ann. rheum. Dis., 19, 174.

Wadia, N., and Williams, E. (1957). Brain, 80, 59.

Whitty, C. W. M. (1958). Neurology, 8, 389.

Polyarthrite dans le complexe symptomatique multiple de Behçet

\section{RÉSUMÉ}

On enregistre deux cas de complexe symptomatique multiple de Behçet, dans lesquels une arthrite du type rhumatismal persistant constituait le trait manifeste et prédominant. On passe en revue la littérature pertinente aux aspects arthritique et arthralgique et on discute le diagnostic différentiel. On indique les bornes de la conception de triade. On suggère que la présence des traits n'appartenant pas à la triade devrait faire penser à ce syndrome dans presque tous les cas de symptomatologie vaguement définie.

Poliartritis en el complejo sintomático mültiple de Behçet

\section{SUMARIO}

Se relatan dos casos de complejo sintomático múltiple de Behçet, en los cuales una artritis de tipo reumatoide persistente fué el rasgo manifiesto y dominante. Se pasa revista a la literatura pertinente a los aspectos artrítico y artrálgico y se discute el diagnóstico diferencial. Se indican los límites del concepto de triada. Se sugiere que la presencia de rasgos fuera de la triada deberían hacer pensar a este sindrome en casi todos los casos de sintomatología vagamente definida. 